\title{
Economics of potato (Solanum tuberosum $L$ ) production in Taplejung district of Nepal
}

\author{
KP Timsina ${ }^{*}$, K Kafle ${ }^{*}$, and S Sapkota ${ }^{* *}$
}

\begin{abstract}
Potato is staple crop of high hills in Nepal. It is one of the important crops to address food insecurity in the country. A study on economics of potato production was conducted in Fungling, Dokhu, Nangkholang and Hangdewa VDCs of Taplejung district in September 2010. Altogether 180 potato producers from 13 farmers' group, which received the membership of Commercial Agriculture Alliance (CAA), were taken as sample of the study by using purposive sampling technique. The regression analysis showed that income from potato has significant contribution $(\mathrm{P}<0.01)$ to total income from High Value crops (HVCs). Around 90 percent farmers in the study area were using improved varieties of potato seed such as Desiree, Kufrijoti and Cardinal. The correlation between lowland and upland growers was weakly related $(\mathrm{r}=0.18)$. Average area per household for potato production and its productivity was found 0.75 Ropani and $844 \mathrm{Kg} /$ Ropani, respectively. The cost of production per Kg potato was NRs. 7.3. Means of transportation to district headquarter was by human labor and its cost ranged from NRs. 2-5 per Kg. The transportation cost from Taplejung to Birtamod market was found in between NRs 4-6 depending upon season. Gross margin of potato per Ropani was NRs.15504 and the benefit cost ratio was 2.9.The highest average price of potato (NRs. 32.5 per $\mathrm{Kg}$ ) at Birtamod wholesale market at nearby terai was found in September to October, whereas the highest average price of potato (NRs. 38.7 per $\mathrm{Kg}$ ) at Taplejung market was found in May to June. Findings revealed that access to collection centre, credit facilities, storage facilities and weak backward and forward linkage were the major problems in the study area, whereas suitability of climate, availability of improved technology, improving access to road, and communication were the major strengths for potato production in the district. Findings indicated that there was a high potentiality of commercial potato production and ensuring food security in Taplejung district, however, it will be necessary to suitably adjust by creating time and place utility in future.
\end{abstract}

Key words: Benefit cost ratio, gross margin, profitable, potato and price

\section{Introduction}

Potato is grown in more than 125 countries of the world. The survival of hundreds of millions of people in the developing countries depends on the potato today. China with its

\footnotetext{
* Nepal Agricultural Research Council (NARC). krishnatimsina@yahoo.com

${ }^{* *}$ Food and Agriculture Organization (FAO)
} 
70 million tons per year is the biggest potato producer worldwide ((IYP, 2008). Potatoes are well known for being nutritious. They are rich in carbohydrates, protein and vitamin $\mathrm{C}$, making them a good source of energy. Therefore, potatoes can be an important factor in improving the health of rural populations in developing countries (IYP, 2008). The year 2008 was declared the International Year of the Potato by the United Nations, noting that the potato is a staple food in the diet of the world's population, and affirming the need to focus world attention on the role that the potato can play in providing food security and eradicating poverty.

Nepalese farmers have cultivated potato for 200 years and potato is one of the major food crops in the mid- and high-hills where it is a staple food with an average per capita consumption of $30 \mathrm{Kg} /$ annum (Ojha et al; 2001). Although potato productivity has increased rapidly (by 43\%) over the past 35 years in Nepal, it is still among the lowest in the world (ABPSD, 2008/09). The world's highest yield is recorded in New Zealand; with an average productivity of more than $45 \mathrm{t} / \mathrm{ha}$ (IYP, 2008). Potato is the fourth most important food crop in Nepal after rice, maize, and wheat in term of area coverage, 2nd in the production. It is one of the important crops in the food security program in Nepal since it gives the highest dry matter per unit time and area. It plays vital role in food security and nutrition. The potato produces more nutritious food more quickly, on less land, and in a harsher climate than any other major crop - up to 85 percent of the plant is edible human food, compared to around $50 \%$ in cereals (IYP, 2008). Therefore, potato could be an important crop for national food security and nutrition point of view. Most of the studies have shown that potato production is more profitable than the production of food-grain crops (DoAD, 1992b). The profitability scenarios between potato and competing crops were assessed and found that although potato production are more expensive to produce than cereals, they are also more profitable. The average net return from potato was five times more than that from cereals (DoAD, 1992b). However, various production and marketing related constraints have adversely affected the production of potato in Nepal especially high hills.

Taplejung is a hilly district of Nepal located at Eastern development region and it is not also free from food insecurity problem. About 4440 metric ton of food (cereal) is insufficient in the district (DADO Taplejung, 2009) for consumption. As potato is a major staple food in the hills of Nepal, it might be good option for contributing food security in the district. Moreover, income from potato could be used for buying necessary food as it more profitable than other crops. In this connection, this study was designed to find out the production and marketing potentiality of potato for ensuring livelihood of farmers in Taplejung district as a broad objective, whereas specific objectives were to; find out gross margin, benefit cost ratio of potato, contribution of potato to total income from High Value Crops (HVCs), price analysis for different markets and Strengths, Weaknesses, Opportunities and Threats (SWOT) of potato sub-sector in Taplejung. 


\section{Limitations of the study}

The study was confined in the farmers' group which received the membership of Commercial Agriculture Alliance (CAA) that might create the commercial bias in the results. So, the results may not represent all hilly areas of Nepal. Similarly, during calculation of benefit cost ratio, only variables cost was used as cost of potato production rather than total cost.

\section{Methodology}

\section{Selection of study area and sample}

Taplejung district was selected purposively, as it is only one hilly district of Commercial Agriculture Development Project (CADP) areas. Similarly, Fungling, Dokhu, Nangkholang and Hangdewa village development committees (VDCs) were selected based on distribution of Commercial Agriculture Alliance's (CAA's) membership. One hundred eighty group members (potato growers) from 13 groups (227 members) were selected purposively as a sample for the study.

\section{Data analysis}

The primary and secondary information were collected from the field survey. The collected information were coded, tabulated and analyzed by using Statistical Package of Social Science (SPSS) and Micro-soft Excel for calculating grass margin, benefit cost ratio, correlation analysis, regression analysis. Moreover, SWOT (Strengths, Weaknesses, Opportunities and Threats) analysis was also carried out.

\section{Economic and SWOT analysis}

Gross margin $=$ Gross return - Total variable cost

Benefit- cost analysis $=$ Gross return/Total cost (including only variable costs)

Analysis of contribution of potato production to HVCs income

The effect of different explanatory variables to dependent variable was assessed by running linear regression model. The theoretical model used for the study was;

Income from High Value Crops (HVCs) = (Income from potato, Income from fruits, Income from cash crops). Therefore, the mathematical specification of the model was

$\mathrm{Y}=\mathrm{a}+\mathrm{b}_{1} \mathrm{X}_{1}+\mathrm{b}_{2} \mathrm{X}_{2}+\mathrm{b}_{3} \mathrm{X}_{3 \ldots \ldots \ldots+} \mathrm{bn} \mathrm{X}_{\mathrm{n}}$

Where, $\mathrm{Y}=$ dependent variable

$\mathrm{a}=$ the slope of the equation

b1 ...b2 ....bn $=$ coefficients to estimates

$\mathrm{X}_{1 \ldots .} . \mathrm{X}_{2} \ldots \ldots \ldots . \mathrm{Xn}=$ independent variables

Strength, weakness, opportunities and threat (SWOT) analysis is a tool used to developing strategies for intervention of technology. It was used for identifying SWOT of potato subsector by involving potato stakeholders of the study areas. 


\section{Results and discussion}

\section{Land holding}

The average total land holding in the study area was found 41 Ropani, where majority of their land was pakhobari followed by low land and up land. The respondents having minimum land holding and maximum land holding were found 4.99 and 408 Ropani, respectively. In the Taplejung district, about 20 percent housholds were having 1 to 5 hectares of land (DADO, 2009, Table 1).

Table 1. Land holding $\left(\operatorname{Ropani}^{4}\right)$ in study area

\begin{tabular}{lcccc}
\hline Description & Lowland $^{\mathbf{1}}$ & Upland $^{\mathbf{2}}$ & Pakhobair $^{\mathbf{3}}$ & Total land $^{\text {Page }}$ \\
\hline Average & 14 & 7 & 20 & 41 \\
Minimum & 1.7 & 1.4 & 1.98 & 4.99 \\
Maximum & 98 & 98 & 212 & 408 \\
\hline
\end{tabular}

${ }^{1}$ It is irrigated and bunded land in Nepal as Khetland, ${ }^{2}$ It is unirrigated and unbunded land in Nepal as Bariland

${ }^{3}$ It is a marginal land, normally not used for crop cultivation, ${ }^{4}$ Ropani $=500 \mathrm{~m}^{2}$

\section{Potato production and selling}

Out of total area, average of 0.75 Ropani of land was used for potato production. On an average $636 \mathrm{Kg}$ of potato was produced per household, out of which only $208 \mathrm{~kg}$ was for their own consumption. The results indicated that farmers sold potato up to $5000 \mathrm{Kg}$ per household. The import data of potato indicated that quite significant part of the demand in eastern area was met by supply from India. The growth rate of potato import for last 20 years was $2.3 \%$ (Calculated based on the import data of FAOSTAT, 2008 cited in FBC, 2008), which reflects the potentiality of more potato production and selling in the eastern region of Nepal. The details are given (Table 2).

Table 2. Area, production and selling pattern of potato per household in the study area

\begin{tabular}{lcccc}
\hline Description & Area (Ropani) & Production (Kg) & $\begin{array}{c}\text { Own use quantity } \\
\mathbf{( K g )}\end{array}$ & $\begin{array}{c}\text { Selling quantity } \\
\mathbf{( K g )}\end{array}$ \\
\hline Average & 0.75 & 636 & 208 & 428 \\
Minimum & 0.07 & 60 & 20 & 40 \\
Maximum & 7.18 & 7000 & 2000 & 5000 \\
\hline
\end{tabular}

\section{Potato seed used}

In totality, around 91 percent farmers were found using improve varieties. In Dokhu and Hangdewa VDC, 100 percent farmers used improve varieties; whereas in Nangkholang only 66.5 percent respondents used improved varieties. The reason for using 100 percent improved varieties in Dokhu and Hangdewa might be due declaration of vegetables and potato pocket area in the district for those VDCs (DADO, Taplejung, 2009). The common improved 
varieties used in study area were Desiree, Kurfijoti and Cardinal, however, most of the farmers used seed from their own production every year. The details are given (Table 3 ).

Table 3. Details of potato seed used in the study area

\begin{tabular}{lccc}
\hline \multirow{2}{*}{ Name of VDCs } & \multicolumn{2}{c}{ Seed type } & \multirow{2}{*}{ Total } \\
\cline { 2 - 3 } & Local & Improved & \\
\hline Fungling & $5(4.4)$ & $109(95.6)$ & $114(100)$ \\
Dokhu & $0(0)$ & $18(100)$ & $18(100)$ \\
Hangdewa & $0(0)$ & $19(100)$ & $19(100)$ \\
Nangkholang & $10(34.5)$ & $19(65.5)$ & $29(100)$ \\
Total & $15(8.3)$ & $165(91.7)$ & $180(100)$ \\
\hline
\end{tabular}

Figures in parenthesis indicates percentage

\section{Productivity analysis}

The study indicated that the productivity of potato in the Taplejung district $(11.39 \mathrm{Mt} / \mathrm{ha})$ was relatively lower than National level (13.32 Mt/ha), however, it was higher in the study area (16 Mt/ha) compared to district and national level. Reasons for higher productivity in the might be due to use of improved varieties (Table 4). This finding coincide with the findings of the on-farm verification of potato tuber yield that ranged from 12 to 17 ton/ha as affected by the variety and growing condition (Annual Report, ORD-NARC, 2009).

Table 4. Comparative analysis of potato productivity at different level

\begin{tabular}{lc}
\hline Different level & Productivity(t/ha) \\
\hline National & 13.3 \\
District & 11.3 \\
Study area & 16.6 \\
\hline
\end{tabular}

Source: DoA/VDD- Annual Progress Report, 2009 and Field Survey

\section{Correlation between total land used and potato production}

In correlation analysis, only upland and lowland was taken as total land as it was suitable for potato production. From the study, it was revealed that there was positive a weak positive correlation between total land use and potato production value $(\mathrm{r}=0.184)$. This could be due to more income from the potato which was also a staple food in the district (Table 5). 
Table 5. Correlation between total land use and potato production

\begin{tabular}{llcc}
\hline Variables & Parameter & $\begin{array}{c}\text { Potato production } \\
\text { (Kg) }\end{array}$ & $\begin{array}{c}\text { Total land use } \\
\text { (lowland and upland) }\end{array}$ \\
\hline \multirow{3}{*}{ Production of potato } & Correlation & 1 & 0.18 \\
& Sig. (2-tailed) & & 0.01 \\
& $\mathrm{~N}$ & 180 & 180 \\
\cline { 2 - 3 } & Correlation & 0.18 & 1 \\
Total land used (low land & Sig. (2-tailed) & 0.01 & 180 \\
And upland) & $\mathrm{N}$ & 180 & \\
\hline
\end{tabular}

Note : Correlation (r)-0.184

\section{Gross margin and benefit cost ratio}

The cost of production per $\mathrm{Kg}$ of potato at farm level was found $\mathrm{NRs}^{5} 7.30$ which was higher than the cost of production in India and even in terai districts of Nepal. FBC (2008) reported that the cost of production per $\mathrm{Kg}$ of potato in eastern region of Nepal was NRs 3.68. This was relatively lower than in Taplejung. The reasons were that, in tarai, especially in the commercial areas there were improved practice of potato production. Tractor was used for land preparation and transportation. Operations like planting, weeding, earthing up and harvesting were contracted out to the labor on area basis which costs about $11 \%$ of the total cost of production. But this was not practiced in Taplejung. Most of the farmers sold potato at district headquarter by transporting from labors which ranges from NRs 2-5 per $\mathrm{Kg}$, whereas transportation cost from district headquarter to Birtamod market ranges from NRs 4-6 per Kg. The gross margin per Ropani of potato was recorded NRs 15504. Similarly, the benefit cost ratio was 2.90 (Table 6).

Table 6. Gross margin and benefit cost ratio analysis of potato (per Ropani)*

\begin{tabular}{lc}
\hline Cost of production at farm level $(* * \mathrm{NRs} / \mathrm{Kg})$ & 7.3 \\
\hline Average transportation cost to district headquarter (NRs./Kg) & 2.3 \\
Average transportation cost to Birtamod from district headquarter (NRs./Kg) & 5.0 \\
Total cost (NRs./Ropani) & 8128 \\
Gross margin (NRs/Ropani) & 15504 \\
B/C Ratio & 2.9 \\
\hline
\end{tabular}

*Total income calculated based on the average price of district headquarter @ NRs 28/Kg potato

** Buying rate of 1 US $\$=71.29 \mathrm{NRs}^{5}$ (Nepalese Rupees) as of September 30, 2010

\section{Contribution of potato to HVCs}

For the estimates of the effects of potato income to the income of HVCs, linear regression model was run. The variation covered by the model was satisfactory as $R^{2}$ was 0.926 
(Table 7). All the explanatory variables were found significant $(\mathrm{P}<0.000)$. The contribution of potato $(0.281)$ to HVCs was higher than contribution of fruits $(0.188)$, however the contribution of cash crops (0.814) was recorded higher than potato, as cardamom, turmeric and ginger were the major cash crops in the district (DADO, Taplejung, 2009). From the results, it was revealed that, one rupee increment in potato income can contribute to increase HVCs income by 0.281 rupee (Table 7).

Table 7. Contribution of potato to total HVC's income

\begin{tabular}{lccc}
\hline \multirow{2}{*}{ Model } & \multicolumn{2}{c}{ Standardized coefficients } \\
\cline { 2 - 4 } & Beta & t & Significant \\
\hline (Constant) & 4688.009 & 4.5 & 0.000 \\
Annual income from potato (NRs.) & 0.281 & 15.3 & $0.000^{* *}$ \\
Annual income from cash crop (NRs.) & 0.814 & 42.0 & 0.000 \\
Annual income from fruits (NRs.) & 0.188 & 9.7 & 0.000
\end{tabular}

Dependent Variable: Annual income from HVCs

(NRs.) and $\mathrm{R}^{2}=0.926$, and adjusted $\mathrm{R}^{2}=0.924$

** Means significant at $1 \%$ level of significance

\section{Price and SWOT analysis}

The Price of Taplejung market and Birtamod, nearby terai wholesale market was analyzed from June/July, 2009 to May/June 2010. From the results it was revealed that at Taplejung market, price increased from June/July and it increased at increasing rate up to NRs 38. 75 per Kg at May/June 2010. However, at Birtamod market price increased from June/July and it was only up to September/October, 2009 (NRs 32.5 per Kg) and then gradually decreased. From the study, it was found that months from December to May was not favorable to sold potato at Birtamod market. It is reported that it was almost impossible to export the vegetables in Indian markets during main season of production. Since the quantity produced was in commercial scale and there were many incentives for vegetable growers from Indian government both from the state and central level, the produce has lower price than Nepal during that season. Hence, the focus should be given for the off season production that could be fulfilled in the short supplied nearby Indian markets with good price (Oli, 2009). In Taplejung, potato could be produced over the year (DADO Taplejung, 2009). At the present context, there was no problem of marketing for potato in Taplejung district. However, when potato production massively scaled up to commercial production in Taplejung, then there should create time and place utility as cost of production was relatively higher in Taplejung than in India and terai districts of Nepal (Figure 1). 


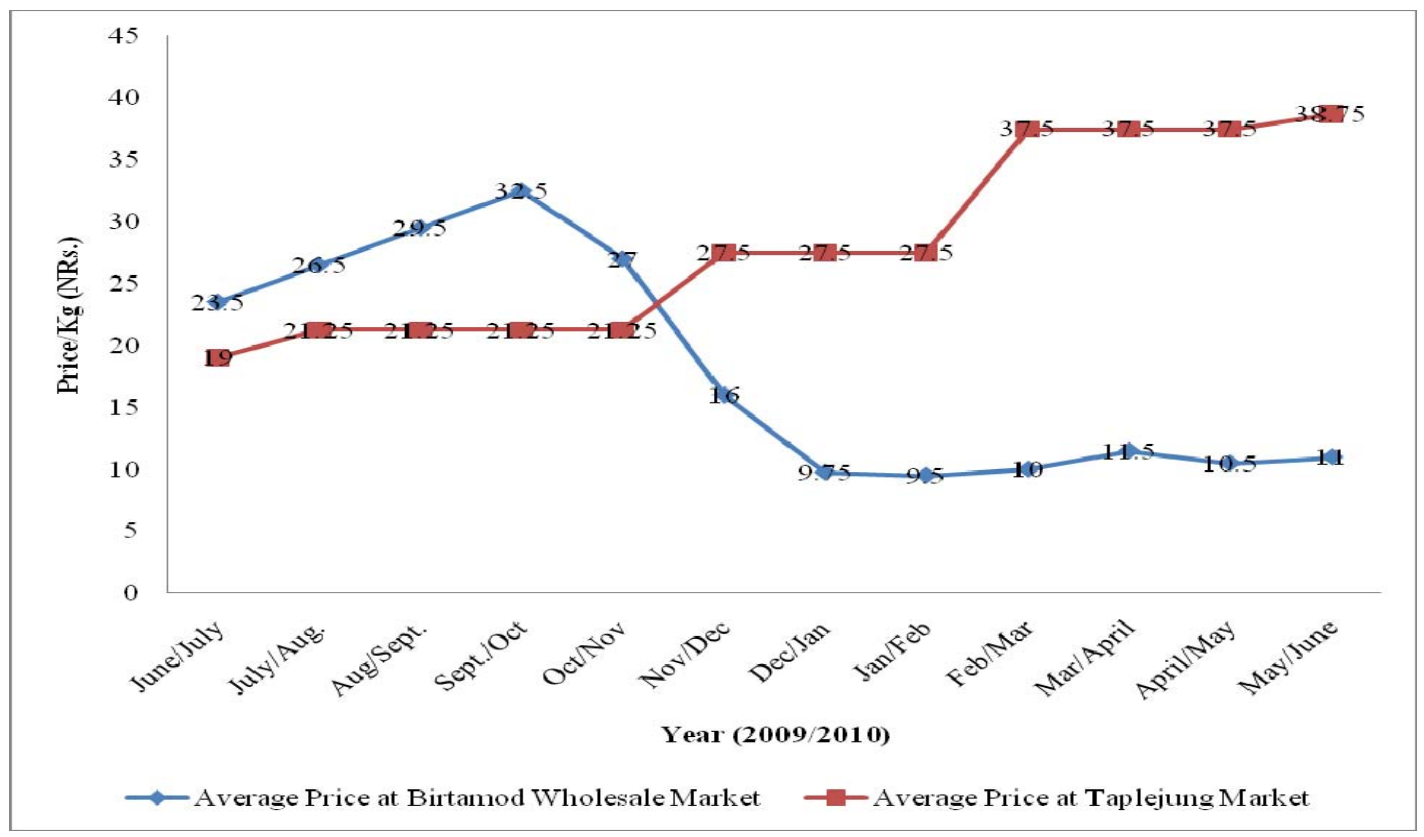

Figure 1. Monthly average price of potato in different markets

The SWOT analysis in Taplejung district could be useful for developing future strategies for potato production. it was observed from the SWOT analysis that high hills were suitable for organic potato production having sufficient indigeneous knowledge of growers as strengths. Still weaknesses were identified with respect to improved technology of potato production including market, storage, value addition, and forward and backward linkages of their produce. However, opportunities were identified in the areas of value addition, income generation, import substitution, product diverversification, and export potentiality. There were threats of price competition with potato produced in Terai in the internal markets, and prevalence of pest complexes in potato production in the study sites.

\section{Conclusion}

The productivity of potato was higher in the study area than in district and national level. The cost of production per $\mathrm{Kg}$ of potato at farm level was found NRs 7.3 and the gross margin per Ropani of potato was recorded NRs 15504. Price of potato at Taplejung market increased from June/July and reached peak in May/June 2010 which was not similar to the price at Birtamod of Jhapa where price of potato was highest in September/October and decreased gradually thereafter when potato production in tarai started. At the present context, there was no problem of marketing for potato in Taplejung district. However, when potato production increased up to commercial scale in Taplejung, there should be beneficial effect of time and place utility. From overall study, it could be concluding that potato is a good option for contributing food security in the district mainly because of its importance as staple crop and secondly as cash crop. 


\section{References}

ABPSD (Agribusiness Promotion and Statistics Division). 2008/2009. Statistical information on Nepalese agriculture. Agri-business promotion and statistics division, Ministry of Agriculture and Cooperatives, Kathmandu, Nepal.

Annual Report, ORD-NARC. 2009. ORD (Outreach Research Division-Nepal Agricultural Research Council, 2008/09 (2065/66), Kathmandu, Nepal.

DADO (District Agriculture Development Office). 2009. A glimpse of annual program and output of Taplejung district in 2008/09.

DoA/VDD (Department of Agriculture/Vegetable Development Directorate). 2009. Annual progress report. Government of Nepal/ Ministry of Agriculture and Cooperatives/ Department of Agriculture/Vegetable Development Directorate, Khumaltar, Lalitpur.

DoAD (Department of Agricultural Development). 1992b. Costs of production and returns of major crops in Nepal. Economic Analysis Division, Harihar Bhawan, Lalitpur, Nepal.

FBC (Full Bright Consultancy Pvt. Ltd. 2008. Value chain analysis of potato in Commercial Agriculture Development Project (CADP) Areas. Report submitted to CADP.

IYP (International Year of Potato). 2008. International year of the potato. Potato world. Retrived on March 28, 2008 from http://www.potato2008.org/en/world/asia.html \& (http://en.wikipedia.org/ wiki/International-Year- of_the_Potato. Downloaded on 24th Dec. 2010.

Ojha, DN, OA Hidalgo, and TL Lama. 2001. A Report on informal high quality seed-potato production and marketing by seed producer groups in Nepal. From the lab to the land, research for the 21st century, program report, International Potato Center, Lima, Peru. p. 245.

Oli, P. 2009. Export Potentiality of Fresh Fruits and Vegetables in bordering cities of Uttar Pradesh: A Case Study from www.agripricenepal.com/newsdoc/20090723132720.pdf. Downloaded on 28th April, 2011.

UNDP (United Nations Development Programme). 2007. United Nations General Assembly Verbatim Report meeting 15 session 62 page 32, Mr. Gutiérrez Reinel Peru on 2 October 2007.http://www.sdc.admin.ch/en/Dossiers/Dossier_Potato/Food_security). Downloaded on $10^{\text {th }}$ Aug. 2010. 